See discussions, stats, and author profiles for this publication at: https://www.researchgate.net/publication/341087740

\title{
The last acceptable prejudice in Europe? Anti-Gypsyism as the obstacle to Roma inclusion
}

Article in Group Processes \& Intergroup Relations · May 2020

DOI: $10.1177 / 1368430220907701$

CITATIONS

10 authors, including:

Anna Kende

Eötvös Loránd University

85 PUBLICATIONS 705 CITATIONS

SEE PROFILE

Bigazzi Sara

University of Pécs

34 PUBLICATIONS 38 CITATIONS

SEE PROFILE

Some of the authors of this publication are also working on these related projects:

Project Acculturation and meta-perceptions of acculturation processes View project

Social representation of heroes and heroic acts View project
356

Márton Hadarics

Eötvös Loránd University

18 PUBLICATIONS 121 CITATIONS

SEE PROFILE

Mihaela Boza

Universitatea Alexandru Ioan Cuza

11 PUBLICATIONS 39 CITATIONS

SEE PROFILE 


\section{The last acceptable prejudice in Europe? Anti-Gypsyism as the obstacle to Roma inclusion}

First Published May 1, 2020 Research Article

https://doi.org/10.1177/1368430220907701

Anna Kende ${ }^{1 *}$, Márton Hadarics ${ }^{1}$, Sára Bigazzi ${ }^{2}$, Mihaela Boza ${ }^{3}$, Jonas R. Kunst ${ }^{4}$, Nóra Anna Lantos $^{1}$, Barbara Lášticová ${ }^{5}$, Anca Minescu ${ }^{6}$, Monica Pivetti ${ }^{7}$, Ana Urbiola ${ }^{8}$

*Corresponding author

1 ELTE Eötvös Loránd University, Budapest

2 Department of Psychology, University of Pécs, Hungary

3 Department of Psychology, Alexandru Ioan Cuza University of Iaşi, Romania

4 Department of Psychology and Center for Research on Extremism, University of Oslo, Norway

5 Institute for Research in Social Communication, Slovak Academy of Sciences, Bratislava

6 Department of Psychology, University of Limerick, Ireland

7 Department of Psychological, Health and Territorial Sciences, University of Chieti-Pescara, Chieti, Italy

8 Department of Psychology, University of Jaen, Spain

Full citation:

Kende, A., Hadarics, M., Bigazzi, S., Boza, M., Kunst, J. R., Lantos, N. A., Lášticová, B.,

Minescu, A., Pivetti, M., \& Urbiola, A. (2020). The last acceptable prejudice in Europe? AntiGypsyism as the obstacle to Roma inclusion. Group Processes \& Intergroup Relations. (advance online publication) https://doi.org/10.1177/1368430220907701 


\section{Abstract}

National and European policies aim to facilitate the integration of Roma people into mainstream society. Yet, Europe's largest ethnic group continues to be severely discriminated. Although prejudice has been identified to be at the core of this failure, social psychological research on anti-Gypsyism remains scarce. We conducted a study in six countries using student and community samples $(N=2,089$; Hungary, Romania, Slovakia, Norway, Italy, Spain) to understand how anti-Gypsyism among majority-group members predicts unfavorable acculturation preferences toward Roma people. Openly negative stereotypes predicted acculturation preferences strongly across the countries. However, stereotypes about the Roma receiving undeserved benefits were also relevant to some degree in East-Central Europe, implying that intergroup relations are framed there as realistic conflict. Stereotypes about traditional Roma culture did not play a central role in acculturation preferences. Our findings highlighted that anti-Gypsyism may be an impediment to integration efforts, and efforts should be context-specific rather than pannational.

Keywords acculturation, anti-Gypsyism, cross-cultural research, integration, prejudice 
Roma people, the largest, transnational ethnic minority group in Europe (estimated to be 10-12 million people; Bernát \& Messing, 2016), are frequent targets of hate crimes and discrimination in interpersonal and institutional contexts (European Union Agency for Fundamental Rights [FRA], 2016). Anti-Gypsyism ${ }^{1}$ (i.e., prejudice against the Roma) is present in all European countries (FRA, 2018). Yet, European politics only recently recognized the importance of identifying the unique constituents of this form of prejudice (European Commission, 2004). An important step towards this was coining the term antiGypsyism to draw attention to the prevalence of prejudice against Roma people and to its unique characteristics.

Furthermore, social psychologists, despite their commitment to studying intergroup processes and prejudice, have paid little attention to this phenomenon compared to other forms of ethnic and racial prejudice (for exceptions, see Bigazzi \& Csertö, 2016; Dalsklev \& Kunst, 2015; Dunbar \& Simonova, 2003; Kende, Hadarics, \& Lášticová, 2017; Kteily, Bruneau, Waytz, \& Cotterill, 2015; Ljujic, Vedder, Dekker, \& van Geel, 2013; Orosz et al., 2018; Pérez, Moscovici, \& Chulvi, 2007; Urbiola, Willis, Ruiz-Romero, \& Moya, 2018; Váradi, 2014; Villano, Fontanella, Fontanella, \& Di Donato, 2017). This neglect is problematic because various national and European-level policies on Roma integration resulted in little overall improvement in the situation of the Roma (see Sándor et al., 2017). Although there are areas of progress, the gap between Roma and non-Roma populations keeps widening: Roma people continue to be systematically disadvantaged in housing, employment, education, health, and life expectancy (see Bojadjijeva, 2015; Cook, Wayne, Valentine, Lessios, \& Yeh, 2013).

It has been suggested that prejudice is at the core of this failure: the widespread homogenizing negative attitudes toward Roma people may be both a psychological burden (see Csepeli \& Simon, 2004) and a source of legal and institutional discrimination (FRA, 2018). An analysis of government strategy documents promoting Roma inclusion in Romania, for example, revealed that despite its progressive explicit goals, the association between Roma people and criminality uncritically appeared in all of the documents and created an invisible obstacle to social inclusion (Popoviciu \& Tileagă, 2019). These results suggest that macro-level efforts to change the situation of Roma people in society may fail on individual-level prejudice toward Roma people that results in resistance to Roma integration efforts. Nevertheless, empirically supported explanations of how prejudice creates obstacles to Roma integration are largely missing in both academic and policymaking domains. Therefore, the aim of our research is to explore the characteristics of 
anti-Gypsyism and to show how prejudice predicts majority members' preference for contact with the Roma and their culture maintenance (i.e., Roma integration) in six different European countries.

\section{Anti-Gypsyism Across Europe}

Decades of research suggest the prevalence of modern (McConahay, 1983), subtle (Pettigrew \& Meertens, 1995), implicit (Banaji \& Greenwald, 1994), and aversive (Dovidio \& Gaertner, 1986) expressions of ethnic and racial prejudice over old-fashioned, blatant, explicit, and hostile forms in contemporary democratic societies. However, evidence of prejudice and hate crimes against the Roma suggests otherwise: anti-Gypsyism remains hostile and openly negative (for a critique of interpreting overt forms of prejudice as a phenomenon of the past, see Kende \& McGarty, 2019; Leach, Peng, \& Volckens, 2000). For instance, Kende et al. (2017) showed that prejudice against the Roma is expressed overtly in East-Central Europe because societal norms approve of it.

Furthermore, Roma people are sometimes treated with a severe disregard for human rights even in countries with stronger egalitarian norms. For example, Italy has been condemned for relegating Roma people to nomadic camps (European Roma Rights Centre [ERRC]. 2000), and a survey revealed the commonness of open, direct, and racist attitudes on the one hand, and dehumanization on the other, even among less prejudiced individuals (Fontanella, Villano, \& Di Donato, 2016). Similarly, France has been heavily criticized for collectively criminalizing and deporting Roma people (Castle \& Bennhold, 2010). According to an opinion poll (Dahlgreen, 2015), the Roma minority is the most negatively viewed ethnic group in the Nordic countries of Europe too, with a negative perception ranging from 40 to $72 \%$ of the population within those four countries (Norway, Sweden, Denmark, and Finland). It therefore seems reasonable to ask whether and how antiGypsyism differs from other forms of ethnic and racial prejudice.

There have been attempts to identify the unique characteristics of anti-Gypsyism (Ljujic, Vedder, Dekker, \& van Geel, 2012a), but even these attempts acknowledge that antiGypsyism stems from the same psychological motivations as other forms of prejudice. Therefore, most studies acknowledge the importance of general tendencies towards prejudice in explaining anti-Gypsyism, such as authoritarianism (Dunbar \& Simonova, 2003; Todosijevic \& Enyedi, 2002), social dominance orientation (Zick, Küpper, \& Hövermann, 2011), and nationalism (Csepeli, 2010). Beyond the general tendencies, there is an agreement that anti-Gypsyism contains negative stereotypes about criminality and 
laziness (e.g., Enyedi, Fábián, \& Sik, 2004), and depicts the Roma as an incompetent and cold outgroup within the framework of the stereotype content model (e.g., Bye, Herrebrøden, Hjetland, Røyset, \& Westby, 2014). The prevalence of overtly negative attitudes fits with the treatment of Roma people across Europe ( $\mathrm{Ng}, 2017)$, which is overtly hostile regardless of existing regional differences in the endorsement of multiculturalism (see e.g., Tremlett \& Messing, 2015), and in norms regarding the expression of prejudicial attitudes (for the effect of changing norms on prejudice expression in Western Europe, see Pettigrew \& Meertens, 1995; for a direct comparison of the normative context and prejudice cross-nationally in Europe, see Hello, Scheepers, \& Gijsberts, 2002).

Roma people in Eastern Europe are often seen as taking advantage of the welfare system by receiving too many and undeserved benefits, creating the perception of a realistic group conflict (Sherif, 1966) between the majority and the Roma minority (e.g., Cooper, 2001). The idea that limited resources are distributed unfairly, favoring the minority group, corresponds with the concept of modern racism (McConahay, 1983). Modern racism is often justified by meritocratic beliefs suggesting that benefits need to be earned and not handed out unconditionally (see Coenders, Scheepers, Sniderman, \& Verberk, 2001; Kuklinski et al., 1997). Furthermore, these ideas fit with the specific stereotypes about the Roma regarding criminality and laziness. The prevalence of these stereotypes in East-Central Europe may be reinforced by the characteristics of the respective cultural contexts: Roma people constitute a large minority group (often close to $10 \%$ of the population) and the population of Roma people is growing more rapidly than that of the majority population. Perceived growth of a minority population has been identified as a source of growing prejudice (in line with the concept of realistic threat; Stephan \& Stephan, 2000), and overestimation of the population is often used to justify constrictions against a minority group (Clark, 1998). Therefore, attitudes toward Roma people, in countries with a large Roma population, can be shaped by the belief that Roma people are a financial burden to society (Loveland \& Popescu, 2016). This may be particularly pivotal if citizens consider their economic resources limited and themselves poor, such as in the case of East-Central Europe, which includes the poorest countries of the continent (European Union, 2019).

Finally, some studies revealed stereotypes about cultural difference that reflect a romantic image of the carefree life of Roma people that the non-Roma majority living in modern, urban, and industrialized social contexts can idealize (Villano et al., 2017). However, this seemingly positive image may have negative consequences as it ties Roma people to the 
past and culturally distances them (Kligman, 2001; Sigona, 2005). Although Roma people are associated with musical talent everywhere, their perception as a culturally different outgroup has been found mostly outside East-Central Europe (Bigazzi, 2012). Here, ethnocultural stereotypes are often combined with anti-immigrant sentiments, because the Roma minority consists of both a historical Roma minority population (i.e., a more romanticized "nomadic" Roma group) and recent immigrant groups from Eastern Europe (López Catalán, 2012). In sum, studies from different regions of Europe have shown that antiGypsyism can consist of (a) traditional negative stereotypes about violations of moral principles wherever Roma people live, (b) depictions of the Roma as unfair competitors for limited resources in Europe's poorer countries where Roma people constitute a large minority group and as (c) a culturally different outgroup mostly outside East-Central Europe where Roma people constitute a small minority group, some members of which maintain a traditional lifestyle (corresponding with our earlier findings in Kende et al. [2017]). Although this conceptualization synthetizes the main findings of anti-Gypsyism research, it focuses mostly on prejudice content. Admittedly, there are other ways of characterizing prejudice against Roma people, for example, by focusing more directly and specifically on intergroup emotions (for research on threat, see Ljujic et al., 2013) or measuring the level of dehumanization (Bruneau, Szekeres, Kteily, Tropp, \& Kende, 2019). Both constructs can predict behavioral intentions but capture the specific characteristics of anti-Gypsyism less.

\section{Acculturation Preferences from a Majority Perspective}

Berry's acculturation model (Berry, 1997) is undoubtedly the most influential theory describing the psychological processes of intercultural influence. According to this model, immigrant groups can experience four types of acculturation outcomes-integration, assimilation, separation, and marginalization — based on (a) preferences for maintaining their original culture and (b) the desire for contact with members of the majority. Integration (i.e., the desire to maintain one's original culture and to have contact with the majority) is related to better psychological and health outcomes than all other acculturation strategies (e.g., Phinney, Horenczyk, Liebkind, \& Vedder, 2001), and it is associated with more positive intergroup attitudes (Zagefka \& Brown, 2002; Zagefka, Brown, Broquard, \& Martin, 2007). It is equally important that it corresponds with the dominant values of Western societies, such as egalitarianism, universalism, and multiculturalism. Therefore, it is also politically the most favorable form of intergroup relation between majority and minority groups. The term integration is often replaced by "inclusion" and "access" in 
policy documents to emphasize that majority institutions need to contribute to contact and culture maintenance more (Carrera, 2016).

Because of the power asymmetry between majority and minority groups, acculturation outcome for minority groups is considerably determined by the preferences of the majority, as shown in the case of Roma people (Ljujic, Vedder, Dekker, \& van Geel, $\underline{2012 b}$ ). There is vast empirical support for the association between majority members' intergroup attitudes and acculturation preferences for minority groups, suggesting that prejudice is associated with a preference for low contact with and culture maintenance of the outgroup (e.g., Kunst, Sadeghi, Tahir, Sam, \& Thomsen, 2016; Piontkowski, Florack, Hoelker, \& Obdrzálek, 2000; Zick, Wagner, van Dick, \& Petzel, 2001). In sum, a prejudiced majority group can obstruct the integration efforts of the minority group.

Intergroup prejudice has been considered the outcome of acculturation preferences in cross-sectional studies, especially when the studies focused on recent immigrant groups (e.g., González, Sirlopú, \& Kessler, 2010; Zagefka, Brown, \& González, 2009). Yet, other studies viewed acculturation preferences as outcomes of prejudice (Kunst et al., 2016). Considering that intergroup attitudes toward the Roma are deeply historically embedded and stable over time (see Stokes, 2015), we tested the effect of prejudice on acculturation preferences to help understand how integration efforts continue to fail when majority members endorse anti-Gypsyism. Nevertheless, we acknowledge that general attitudes toward integration can also affect prejudice (as shown by longitudinal evidence, Zagefka et al., 2014) by providing justification for acculturation preferences. However cross-sectional survey research cannot determine causal influence, as is the case in our research.

Roma people comprise mainly settled communities, therefore the dynamic relationship outlined in the original description of acculturation theory in connection with immigrant groups may not be directly applicable to the Roma minority. However, one of the main challenges in improving the lives of Roma people and create access for them to mainstream education, housing, health care, and labor market is the geographical and institutional segregation that Roma people experience in all European countries (European Commission, 2004). Segregation creates an obstacle for contact, and consequently a preference by members of the majority that Roma people either continue to live in segregation (isolation) or assimilate into the majority society by abandoning their Roma culture and identity. Showing willingness to engage in contact with Roma people and acknowledging the importance of maintaining Roma culture and identity reflect 
preferences for mutual cultural adaptation that are in contradiction with centuries of mainstream practices that maintained segregation and marginalization. This suggests that despite the settled status of this group, acculturation remains a relevant construct for understanding intergroup relations between non-Roma majority and Roma minority groups, as shown by previous research (Ljujic et al., 2012b).

Historical evidence (Barany, 2000) and (populist) political mobilization strategies suggest that many majority members of European nations have a preference for assimilation and segregation when it comes to Roma people (e.g., Stewart, 2012). These preferences are in stark contrast with efforts of integration (i.e., a preference for both cultural maintenance and contact) that appear in EU directives, some national policies, and the work of NGOs (Marushiakova-Popova \& Popov, 2015). Therefore, the aim of our study is to understand the connection between anti-Gypsyism and acculturation preferences in countries from different European regions, specifically in Hungary, Romania, Slovakia, Norway, Italy, and Spain.

Negative attitudes toward Roma people are widespread in all of these countries according to opinion poll data about social distance, the experience of discrimination, and hate crimes (see e.g., European Commission, 2015). Nonetheless, there are notable differences between them. The countries differ in the size of their Roma population, history of Roma people, cultural heterogeneity of Roma communities, wealth, and the strength of the norms of egalitarianism and multiculturalism. Hungary, Romania, and Slovakia have high Roma populations, consisting almost exclusively of settled communities who have lived in the region's countries since the Middle Ages. It is estimated that in all of these countries the Roma make up 5 to $10 \%$ of the overall population, however, data are unreliable because of the lack of official ethnic registry and people preferring not to identify as Roma in censuses (on the estimated size of the Roma population in Slovakia, see Mušinka, Škobla, Hurrle, Matlovičová, \& Kling, 2014; in Hungary, see Pásztor \& Pénzes, 2013; in Romania, see Roma Education Fund, 2012). Both Italy and Spain have an indigenous Roma population as well as a Roma population from Eastern Europe who arrived following the EU enlargement in 2004 and 2007 (Magazzini \& Piemontese, 2016). The size of the Roma population is estimated $0.25 \%$ in Italy (European Commission, 2018) and around $1 \%$ in Spain (López Catalán, 2012). Although Norway too can trace back the presence of Roma people (i.e., "Norwegian Travellers") to the Middle Ages, the current Roma population consists mainly of recent immigrants from Eastern Europe. It is estimated to be between 0.08 and $0.2 \%$ of the overall population (Rosvoll \& Bielenberg, 2012). 
There are vast differences between the countries included in this research in terms of economic well-being: Norway is one of the richest countries in Europe; Hungary, Slovakia, and Romania are among the poorest; Italy and Spain also face economic hardships and instability, but their GDP is significantly higher than the GDP of EastCentral European countries (European Union, 2019). Cross-cultural research indicates that the countries also differ in values that are associated with egalitarianism and openness to cultural differences (see e.g., Schwartz \& Bardi, 2001), and in indicators of multiculturalism (see e.g., differences in Migrant Integration Policy Index [MIPEX] scores in connection with migrant integration at http://mipex.eu). Generally, Roma people tend to live in larger numbers in poorer countries with weaker egalitarian values.

\section{Hypotheses}

We formulated our hypotheses based on the three main dimensions of attitudes toward the Roma in different European countries: (a) blatantly negative stereotypes about criminality and laziness, (b) perception of the Roma as the recipients of undeserved benefits, and (c) as a culturally different outgroup (for these three aspects of attitudes toward Roma people, see Kende et al., 2017).

- H1: We hypothesized that blatant negative stereotyping would predict preferences for low contact and low culture maintenance (i.e., rejecting integration) in all cultural contexts.

- H2: We expected that ideas about Roma people receiving undeserved benefits would be a stronger predictor of preferences for low contact and culture maintenance in EastCentral Europe than outside this region, as any policy favoring Roma people is often interpreted as realistic conflict in this context (Cooper, 2001; Weinerová, 2014).

- H3: Ideas about positive cultural difference would be more important predictors of integration outside East-Central Europe, predicting higher contact and cultural maintenance preferences in Southern and Northern Europe (Sigona, 2005), considering that the cultural dimension of Roma representations is more typical outside East-Central Europe (see e.g., Bigazzi, 2012).

\section{Method}

\section{Participants}


The target sample size was calculated for the confirmatory factor analysis of the antiGypsyism measure. A priori sample size calculations for Hungary and Slovakia were made for the development of the Attitude Toward the Roma Scale using a rule of thumb in the absence of earlier research. Results of scale development were partially (using parts of the current data set from Hungary and Slovakia) published in Kende et al. (2017). Forty items were included in the first version of the scale, therefore we attempted to recruit 400 participants (the process of scale development is described in Kende et al. [2017]). For the additional four countries of the current research, we determined the optimal sample size based on the results from Hungary and Slovakia. Besides the number of variables, communalities are recommended to be taken into account for calculating sample size for factor analysis (MacCallum, Widaman, Zhang, \& Hong, 1999). With the low communalities of some of the items ( $>$.2), the adequate sample size for the three-factorial solution was $N>300$. This was not reached in Norway, therefore results from this sample need to be treated with caution.

We used different forms of compensation in the different contexts, which may have influenced social desirability bias, although instructions made it clear that the compensation was independent from the answers provided in the questionnaire, and compensation was relatively low (for ethical and practical consideration of participant payment, see Largent, Grady, Miller, \& Wertheimer, 2012). Convenience sampling was used in all six contexts, but some samples were more diverse than others. We could have opted for recruiting only students to make multigroup comparisons more feasible.

However, because of the well-known limitations of relying exclusively on student samples for the study of complex social issues such as intergroup prejudice (see Sears, 1986), we aimed for the inclusion of more diverse participants. Nevertheless, we kept two samples in the study consisting of only students. Data from Hungary consisted of students from all disciplines where participants completed the questionnaire for course credit. This sample did not differ from the general population in the level of anti-Gypsyism-based on the scores of the feeling thermometer in this sample: $M=41.05, S D=21.36$ on a scale from 0 to 100 ; in comparison with data from nationally representative samples: $M=4.27, S D=$ 2.25 on a scale from 0 to 10 from a database used in Nariman, Hadarics, Soufizadeh, and $\underline{\text { Kende }(2020)}, t(1469)=1.30, p=.194$-therefore, their inclusion in the study seems justified. In Spain, the questionnaire was completed by psychology and social work students who either received course credit or participated for a $€ 100$ raffle prize. Because this sample consisted of a special subgroup of students, we treat findings from this group with caution and discuss how it may have affected the results in the Discussion section. In 
Romania, Slovakia, Norway, and Italy, data were collected partly among university students and partly by students with the aim of recruiting a more diverse sample in terms of age, gender, level of education, and settlement type. Respondents in Norway and Italy did not receive compensation, students in Romania and Slovakia received course credit. For basic demographic information on the participants and additional information about the questionnaire, see Table 1.

Table 1. Information on participants across samples.

\begin{tabular}{|c|c|c|c|c|c|c|}
\hline & Hangary & Romania & Slovalia & Norway & Italy & Spain \\
\hline $\begin{array}{l}\text { The woed fot Roma people in } \\
\text { the diffetent trimslations of the } \\
\text { qeenticennaite }\end{array}$ & Prems & $\operatorname{Rrom} / i$ & Rómovia & Rombols & Zingato & Gitano \\
\hline Date of data cellection & Nowembxt, 2015 & Mtry-June, 2018 & April-May, 2016 & Apel-Octobst, 2016 & Fifonuary-May, 2018 & $\begin{array}{c}\text { Nowember-December, } \\
2017\end{array}$ \\
\hline$N$ & 432 & 43 & 385 & 214 & 318 & 297 \\
\hline Gendet (N women) & 77.1 & 55.3 & 61.6 & 61.7 & 61.4 & 869 \\
\hline Age in yas" & $21.06(2.09)$ & 37.58 (11.65) & $27.58(11.45)$ & $\begin{array}{c}=125: \\
29.28 \text { (11.83) } \\
==76 ; \\
67.1 \%<25 \\
21.1 \%>25\end{array}$ & 3290 (12.55) & $21.44(3.31)$ \\
\hline $\begin{array}{l}\text { Levd of education } \\
\text { (S. univerity/ongoing univenity) }\end{array}$ & 100 & 38.8 & 35.5 & 58,4 & 55.7 & 100 \\
\hline $\begin{array}{l}\text { Political orikntation } \\
\text { (1 = Left: } 7=\text { Right) }\end{array}$ & $4.20(1.30)$ & $4.21(1.65)$ & $3.31(1.59)$ & $3,76(1.56)$ & $3.6(1.84)$ & $3.11(1.46)$ \\
\hline $\begin{array}{l}\text { Frequency of contast with Roms } \\
\text { peoplet } \\
\text { (6 nare or mo contact) }\end{array}$ & 263 & 425 & 36.1 & 45.8 & 593 & 73.7 \\
\hline
\end{tabular}

\section{Procedure}

We relied on omnibus surveys in Hungary and Slovakia (we present the results of the Attitudes Toward the Roma Scale here and in Kende et al. [2017]), and used a shorter survey to answer the research question of the current paper in the four additional countries.

Data were collected using the Qualtrics online questionnaire platform between 2015 and 2018 (exact dates are shown in Table 1) with IRB approval from the universities involved in the research (Eötvös Loránd University and Oslo University). Items of the questionnaire were translated from English to all six languages and back-translated by independent translators. We report all results and data exclusions connected to our research question (the databases are available at https://osf.io/789vp/?view_only=2f30870801574e52b4a40ab6f68fed7b). We included the responses of all participants who answered the items related to the variables of the hypotheses (additional variables and demographic information were presented later in the questionnaire). Missing values were either negligible or none in all samples, and they were missing at random according to Little's MCAR analysis $(p>.05)$. We checked for outliers using Z-scores. Responses $3 S D$ s above and under the means were inspected but kept in the 
analysis as they did not seem to be data errors, and their number was low (under $0.01 \%$ in all samples). We conducted all the statistical analyses using IBM SPSS Version 22.0 and AMOS 20 (Arbuckle, 2011).

\section{Measures}

We administered the Attitudes Toward the Roma Scale (ATRS) consisting of 16 items (Kende et al., 2017). ${ }^{2}$ Items of the scale were borrowed from previously used measures of anti-Gypsyism (direct adaptation of items from Dunbar \& Simonova, 2003; Enyedi et al., 2004), measures of modern racism (adapted to the context of Roma from Dovidio \& Gaertner, 2000; Pedersen, Beven, Walker, \& Griffiths, 2004), and developed based on nonsurvey research (Bigazzi, 2012; Lášticová \& Findor, 2016). Items of the main variables of the study are presented in the Appendix. Respondents expressed their agreement with the items on a 7-point scale $(1=$ completely disagree, $7=$ completely agree $)$ on all measures, unless otherwise indicated. The advantage of using this scale as opposed to nonspecified measures of prejudice is that, on the one hand, it contains both overt and veiled prejudice items (similarly to the blatant and subtle subscales of Pettigrew \& Meertens, 1995), and on the other hand, it contains items that are specific for antiGypsyism based on previous research in this intergroup context. However, the disadvantage of using ATRS is that it does not allow us to compare prejudice level and the relationship patterns between variables with other intergroup contexts.

We relied on Zagefka and Brown's (2002) five-item Acculturation Preferences Scale of majority groups, consisting of two subscales: Contact Preference and Preference for Culture Maintenance. We used the subscales as continuous variables in line with Zagefka et al. (2007), and as recommended by other studies (e.g., Kunst et al., 2016; Rudmin \& Ahmadzadeh, 2001), rather than creating the four acculturation outcome categories of Berry's taxonomy (1997).

Additionally, we administered measures of prejudice to check the validity of the ATRS across cultural contexts. We measured social distance with the Bogardus Scale (Bogardus, 1925), where respondents indicated the closest social relationship that they would personally accept with a Roma person using 5 scale points ( 1 = accepting as a member of the family, 2 = colleague, 3 = neighbor, 4 = inhabitant of my town, $5=$ none of the above). It must be noted that although the Bogardus Scale has been used to measure prejudice for almost a century, it in fact measures relationship closeness, which can be interpreted as a form of contact. Therefore, correlations between this scale and the study variables were 
checked to rule out the possibility that measures of prejudice and measures of acculturation preferences reflect identical psychological constructs. We used a single-item feeling thermometer to measure likability on a 0 (very unlikeable) to 100 (very likeable) scale. We used the 10-item SDO-6 (Social Dominance Orientation Scale by Sidanius \& Pratto, 1999; shortened by Duckitt, 2001) to test support for between-group hierarchies. In addition, we administered the 10-item version of the Motivation to Respond Without Prejudice Scale by Plant and Devine (1998), with two subscales: a five-item External Motivation Scale (EMS) and a five-item Internal Motivation Scale (IMS) in order to check how different subscales of anti-Gypsyism are associated with genuine (non)prejudice, or alternatively, with the effort to appear politically correct. (One item of the EMS was omitted for lack of fit in the Hungarian sample, and consequently removed from all other samples: "If I acted prejudiced toward Roma people, I would be concerned that others would be angry with me.")

\section{Analytic procedure}

Our analysis comprised two parts. To test whether anti-Gypsyism qualitatively differs between samples, we conducted confirmatory factor analysis (CFA) and tests of measurement invariance following the procedures outlined by Vandenberg and Lance (2000). Second, we used a multigroup path model to test the associations between the different dimensions of anti-Gypsyism and acculturation preferences across the samples.

\section{Results}

\section{Factor analysis}

We tested measurement invariance of the three-factor structure of the ATRS (see Kende et al., 2017) across the samples. We set up four different multigroup CFA models to test for measurement invariance (Vandenberg \& Lance, 2000). Configural invariance was tested by a model where the basic factorial structure was constrained to be invariant across samples. This model showed an appropriate fit to our data (see Table 2), suggesting the same factorial structure in all six samples. However, higher levels of measurement invariance were not satisfied because the multigroup model with metric invariance (with constrained factor loadings) showed a significantly worse fit than the previous model, and the model with scalar invariance (with constrained factor loadings and intercepts) showed an even worse fit than the model with metric invariance. The fourth model with full uniqueness across our samples (with constrained factor loadings, intercepts, and error 
variances) showed the worst fit, significantly worse than the model with scalar invariance (see Table 2). In sum, because configural invariance was achieved, we can assume that participants from different countries conceptualized the three main dimensions of attitudes toward the Roma similarly, enabling us to investigate further the correlates of these dimensions, but not allowing direct comparisons of the level of anti-Gypsyism.

Table 2. Fit indices of the measurement invariance models.

Table 2. Fit indices of the measurement invariance models.

\begin{tabular}{|c|c|c|c|c|c|c|c|c|c|}
\hline Model & $\chi^{2}$ & $d f$ & $\mathrm{CFI}$ & RMSEA & SRMR & AIC & $\begin{array}{c}\Delta \chi^{2} \text { (compared } \\
\text { to the previous } \\
\text { model) }\end{array}$ & $\begin{array}{c}\Delta d f \text { (compared } \\
\text { to the previous } \\
\text { model) }\end{array}$ & $\begin{array}{l}p\left(\Delta \chi^{2}\right. \\
\text { tests })\end{array}$ \\
\hline $\begin{array}{l}\text { Multigroup: } \\
\text { Configural invariance }\end{array}$ & 1281.45 & 606 & .939 & .02 & .07 & 1893.45 & - & - & - \\
\hline $\begin{array}{l}\text { Multigroup: Metric } \\
\text { invariance }\end{array}$ & 1663.22 & 686 & .912 & .03 & .10 & 2115.22 & 381.77 & 80 & $<.001$ \\
\hline $\begin{array}{l}\text { Multigroup: Scalar } \\
\text { invariance }\end{array}$ & 3977.27 & 766 & .711 & .05 & .08 & 4269.27 & 2314.05 & 80 & $<.001$ \\
\hline $\begin{array}{l}\text { Multigroup: Full } \\
\text { uniqueness }\end{array}$ & 4657.54 & 846 & .658 & .05 & .08 & 4789.54 & 680.28 & 80 & $<.001$ \\
\hline
\end{tabular}

View larger version

\section{Descriptive statistics}

Information on the internal consistency of the scales, means, standard deviations, as well as correlations between the variables can be found in Table 3 . Because of the lack of metric and scalar equivalence across samples, we did not conduct direct comparisons cross-culturally. However, the means of the feeling thermometer and the Bogardus Scale reflect a higher rejection of Roma people in the Hungarian, Romanian, and Slovak samples than in the other three contexts, and according to these measures, the lowest level of prejudice was in the Spanish sample, followed by the Norwegian and Italian samples.

Table 3. Scale reliability information, descriptive statistics, and correlations between the variables of the study in all six samples. 


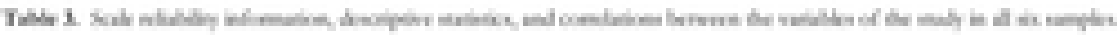

\begin{tabular}{|c|c|c|c|c|c|c|c|c|c|c|c|c|}
\hline Heing & $=$ & $\mathbf{H}$ & III & 2 & 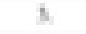 & i & A & it & ${ }^{*}$ & a. & it & $\mathrm{kn}$ \\
\hline 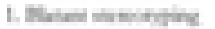 & nit & ait & int & $3 y=$ & $-\mathrm{sin}$ & -15 & 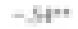 & In- & $-5 i$ & $A F$ & 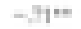 & H. \\
\hline 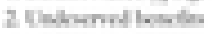 & $=$ & Ent & ent & & - 베 & $-4 y=$ & $-\omega^{\mu}$ & $i=$ & $-4=$ & $\mathrm{su}$ & $-5 y=$ & $y=$ \\
\hline Solved filhens & +1 & stit & 10.15 & & & sit- & m & 15 & in & 배내 & Hit:- & i \\
\hline Arumen pother & ant & 17 & แT & & & & wirn & $-1 \mathrm{y}=$ & 네판 & $-90+1$ & $\sin ^{2}$ & $-5 \times$ \\
\hline 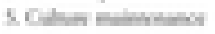 & 7 & E.7\% & Es & & & & & wis & NF & $=$ 배 & the & $=17$ \\
\hline Hasi & $\mathbf{4}$ & 5 & It & & & & & & $-i_{1}$ & iater & $-\pi \mathbf{u}^{n}$ & $3 r$ \\
\hline 7nt & 7 & 114 & $\mathrm{B}$ & & & & & & & $m$ & un & $=5$ \\
\hline ism: & et & $\pm \div$ & $\sin$ & & & & & & & & $-11-$ & 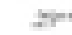 \\
\hline 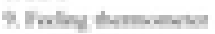 & & 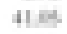 & in & & & & & & & & & $-y=$ \\
\hline in fopuras & & sti & H & & & & & & & & & \\
\hline Limin & $=$ & $\mu$ & 프 & \pm & 1 & it & h & 1 & $E_{1}$ & t. & A & his \\
\hline 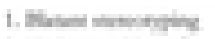 & Ei & ETt & 15 & $m$ & -6 & $-12-$ & $-9 t$ & $15=$ & $-4 \pi$ & $M$ & $-H^{*}$ & at \\
\hline 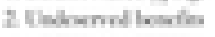 & $=$ & $\tan$ & $\min$ & & $-m$ & -개프 & $-1 \mathrm{n}$ & HF & - 깨반 & inter & -4 & 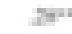 \\
\hline 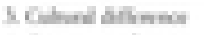 & 1 & 5 & in & & & $I=$ & $H=$ & Hir & H. & -ng & He & ind \\
\hline it revel pother & sivit & E7i & 15 & & & & min & $-1 \mid$ & win & $-m$ & Hin & -5 \\
\hline 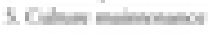 & 7 & घाT & 12 & & & & & in & neis & $m=i$ & Hi: & $=15$ \\
\hline A IDA & = & $1+$ & 117 & & & & & & 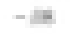 & ynen & $-\pi$ & ITre \\
\hline Fint & il & ift & 네I & & & & & & & $m=17=$ & HF: & Hit \\
\hline 1. जासा & H & ant & in & & & & & & & & $-1-$ & $m$ \\
\hline 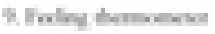 & & ता क्ष & 매난 & & & & & & & & & $=8$ \\
\hline inforige & & 5 & H & & & & & & & & & \\
\hline Anis & $\pi$ & II & III & 2 & 1 & 4. & + & it & N. & i. & \pm & in. \\
\hline 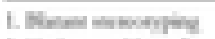 & $=$ & int & ES & $H^{7}=$ & wh & $=45=$ & Enet & $15=$ & Ent" & Mats & $-\mathrm{ST}^{2}$ & il. \\
\hline A Helharnd hath & $=$ & in: & 1룰 & & 17 & -4 th & $-\sin$ & 10 & -54 & At & $-d m$ & atr: \\
\hline 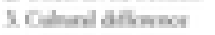 & 11 & $\sin$ & in & & & MP & 此 & $17=$ & Min & $=14$ & IIt & $\operatorname{lng}$ \\
\hline 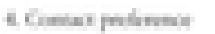 & 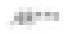 & Eth & 15 & & & & $H$ & $m$ & H" & $-\sqrt{7}$ & tin: & $-\min$ \\
\hline ston & 7 & Ex: & 14 & & & & & -4 & sur & - giri & tyit & $-\pi$ \\
\hline ace: & $=$ & sint & Eis & & & & & & 间 & in & $-M$ & iv \\
\hline tine & $\Rightarrow$ & at1 & at & & & & & & & -4 & win & $-1+11$ \\
\hline E सारा & 됴 & vis: & 배난 & & & & & & & & $m+m=$ & 배 \\
\hline 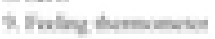 & & 14: & then & & & & & & & & & $-4+4$ \\
\hline In Finthe & & Mit & H & & & & & & & & & \\
\hline Wman & $=$ & II & III & 2 & s. & i. & is & it & I. & i. & it & in \\
\hline 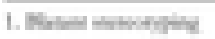 & $=$ & 58 & Lif & $9=$ & Ir: & $=.45$ & $=\sin t$ & 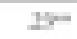 & $=\ldots+$ & 18 & $=18$. & 4 \\
\hline thishomol heth & 4 & 17 & in & & -4 & $-3=$ & $-y+x$ & $y=$ & $-H=$ & then & -+1 & by \\
\hline Sirhudithers & $\$ 7$ & swi & in & & & MH & 1 & in & 3 & 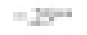 & in & $=11$ \\
\hline 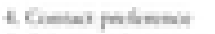 & 5 & $18 \div$ & in & & & & 㘳: & $-m$ & AF" & $-\pi$ & the & $-5 h$ \\
\hline 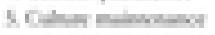 & $m$ & wh. & $w$ & & & & & -17 & 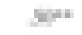 & $-y^{r}$ & In: & -5 \\
\hline Alises & II & 5 & in & & & & & & in & $\mathbf{H}$ & $=H+$ & sir. \\
\hline threl: & $=1$ & at & 111 & & & & & & & -4 & Hon & $-\mathbf{H}$ \\
\hline E. अरा & $y$ & Nath & 패 & & & & & & & & $=x$ & nF. \\
\hline 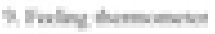 & & miti & 보연 & & & & & & & & & $-14 n$ \\
\hline It Fingula & & 214 & is & & & & & & & & & \\
\hline$h$ & $\Rightarrow$ & 4 & III & 2 & 1 & 4. & s & t & 7 & i. & 4 & Wi. \\
\hline 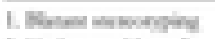 & 푼 & Site & 114 & 15 & $=14$ & min & Inen & $I F$ & $=5$ & In: & mpit: & sy: \\
\hline E Nelownd hoth & 5 & hin & 15 & & int & -yr= & - Er & it & $-m$ & the & $-4 i=$ & $\sin$ \\
\hline 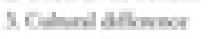 & 4 & 174 & 117 & & & $y=$ & III & $\lambda=$ & H & $-n$ & IIII & -1 in \\
\hline 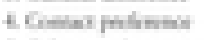 & itrt & $\sin$ & is & & & & $=$ & -15 & sill & $=4+4$ & II. & 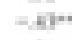 \\
\hline 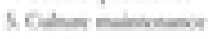 & $\pi$ & 14 & 14 & & & & & -4 & 부눈 & $-2 \mathrm{y}=1$ & Hin & -4 \\
\hline als & $m$ & $y$ & EH & & & & & & 4 & is & 10 & nt \\
\hline Fint & 5 & int & 14 & & & & & & & $-\ln$ & itn & $-\mathrm{at}$ \\
\hline E जाया & $\pi$ & 24 & 10 & & & & & & & & $m=$ & 풀 \\
\hline thulog burames & & Hith & 14. & & & & & & & & & -4 \\
\hline 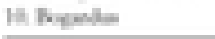 & & 111 & m & & & & & & & & & \\
\hline 해료 & $=$ & 4 & III & 2 & s. & 4 & s. & it & I. & i. & \pm & Hit \\
\hline 1. Whind whoth & n & 24 & wit & $\mathrm{H}=$ & 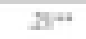 & $=\sqrt{17}=$ & $=5$ & $1=$ & $=5$ & $m=$ & $=5$ & ser. \\
\hline 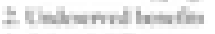 & H & H4 & in & & ither & -13 & $-1+1$ & $i=$ & $-H^{\prime \prime}$ & $H$ & $-\mathrm{H}$ & $\mathrm{sin}$ \\
\hline Arthedunthen & H4 & Ant & $\operatorname{lng}$ & & & 步 & M & $i=$ & -1ent & 14 & -4 & $\sin$ \\
\hline Arumingher & $+\cdots$ & 표 & ISt & & & & Sir. & $=17$ & In: & $=15$ & Hew & $=$ - IIII \\
\hline 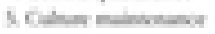 & $=$ & sats & $m$ & & & & & $-1+1$ & Hix & $-M+1$ & Hix & -11 \\
\hline 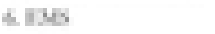 & $\mathrm{s}$ & 251: & $\mathrm{x}$ & & & & & & $=$ 패 & Wh & $=11$ & $\mathrm{ne}$ \\
\hline Hint. & $=$ & his & +7 & & & & & & & $-14=$ & + & $-4 n$ \\
\hline 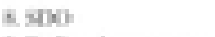 & $\pi$ & 1 믈 & int7 & & & & & & & & $=\sqrt{n+1}$ & wit \\
\hline 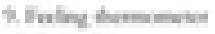 & & 배 & Hith & & & & & & & & & 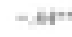 \\
\hline It Fing & & 100 & 14 & & & & & & & & & \\
\hline
\end{tabular}

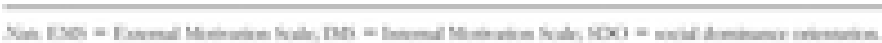

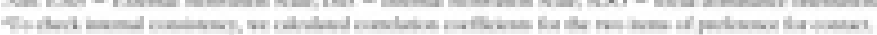

opition.

View larger version 
Across the samples, we found a similar pattern of correlations between the variables that informed us about the validity of the ATRS: blatant negative stereotypes and perceived undeserved benefits were positively correlated in all samples, and negatively correlated with preference for contact and cultural maintenance. They also both positively correlated with other measures (i.e., feeling thermometer, Bogardus Scale, SDO, EMS, IMS), indicating prejudicial attitudes, although more weakly in the case of perceived undeserved benefits. Correlations between the Bogardus Scale and the measure of contact suggest that these are related but distinct constructs, with correlations ranging from nonsignificant to $r=.51, p<.001$. However, patterns varied greatly across contexts regarding the correlations between the cultural difference dimension and other variables. To start with, cultural difference was independent from the other two ATRS factors in most samples, only weakly positively correlated in Slovakia and Spain. In Hungary, Slovakia, and Romania cultural difference correlated positively with the feeling thermometer and EMS, and not with IMS, suggesting that endorsement of these positive cultural difference stereotypes may be an attempt to appear nonprejudiced, rather than the expression of genuinely positive attitudes. The pattern was similar in the Italian sample, however, it also positively correlated with IMS, suggesting that endorsement of these positive stereotypes may reflect more genuinely positive attitudes. Higher acceptance of positively phrased cultural difference items reflected genuinely nonprejudiced attitudes among Norwegian participants based on the positive correlation with IMS, not EMS, and the opposite pattern of correlations in comparison with the other two subscales. Only in the context of Spain, positive cultural stereotypes about the Roma seemed to be an expression of negative attitudes, as the pattern of correlations was the same as that of the other two negative subscales, and cultural difference correlated positively with EMS, and negatively with IMS.

\section{Hypothesis testing}

Using a path model, we checked how the three subscales of attitudes toward the Roma predicted the two dimensions of acculturation preferences. We controlled for the effect of SDO to rule out measuring the effect of a general prejudicial tendency, and also controlled for demographic variables such as gender, age, and level of education. The model was also tested without control variables, and the pattern of connection remained the same (the model without control variables is available in the supplemental material). The results are presented in Figure 1, and statistical details shown in Table 4. 


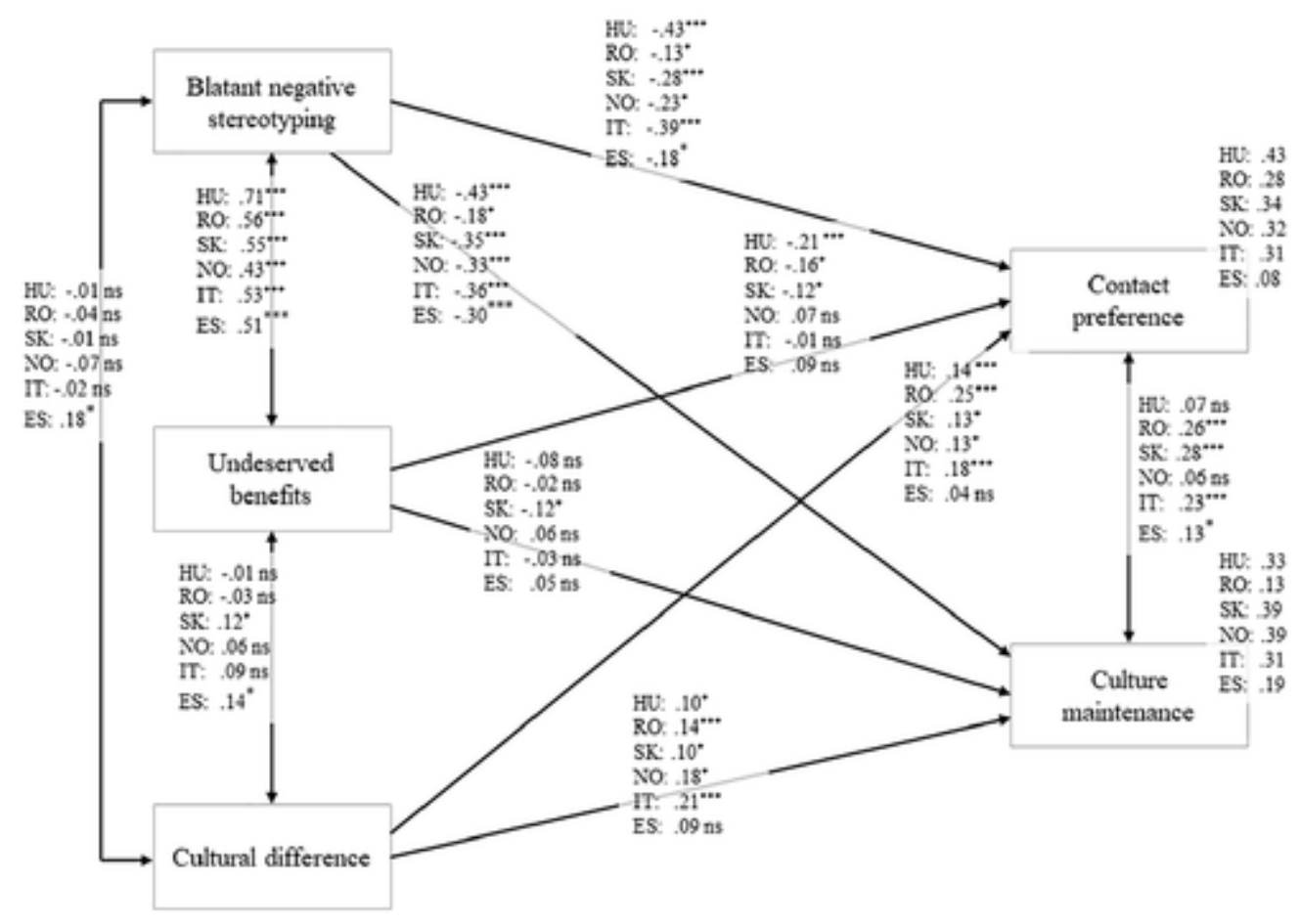

Figure 1. Path model describing the relationship between the three factors of anti-Gypsyism and acculturation preferences using standardized coefficients.

Note. Unstandardized coefficients, exact $p$ values, and confidence intervals are shown in Table 4. SDO, age, gender, and level of education are controlled in the model. $\mathrm{HU}=$ Hungary, $\mathrm{RO}=$ Romania, $\mathrm{SK}=\mathrm{Slovakia}, \mathrm{NO}=$ Norway, IT = Italy, ES = Spain.

$* * * p<.001 . * p<.05$

Table 4. Information on the regression paths of the model in all six samples including SDO, age, gender, and level of education as control variables. 


\begin{tabular}{|c|c|c|c|c|c|c|}
\hline Predictor $\rightarrow$ Oufcoene & $\beta$ & $B$ & SE & $p$ & $1.1 \mathrm{CI}$ & U1C. \\
\hline \multicolumn{7}{|l|}{ Hengany } \\
\hline Bbtant steceotyping $\rightarrow$ Contact preference & -.43 & -0.51 & 0.07 & $<.001$ & -0.64 & -0.36 \\
\hline Btesant shecooryping $\rightarrow$ Cultuec muintenance & -.43 & -0.18 & 0.06 & $<.001$ & -0.69 & -0.26 \\
\hline Undesened berefits $\rightarrow$ Contact perference & -.21 & -0.26 & 0.07 & $<., 001$ & -0.39 & -0.11 \\
\hline Undeserved besefits $\rightarrow$ Culture mainhenance & -08 & -008 & 0.06 & .156 & -0.18 & 0.03 \\
\hline Culnaral difference $\rightarrow$ Contact preference & .14 & 0.21 & 0.06 & $<.001$ & 0.11 & 0.32 \\
\hline Cultural difference $\rightarrow$ Cultues mainterance & .10 & 0.11 & 0.05 & .041 & 0.02 & 0.21 \\
\hline \multicolumn{7}{|l|}{ Romania } \\
\hline Btheant stectoryping $\rightarrow$ Contact preference & -.13 & -0.13 & 0.06 & $<.001$ & -0.25 & -0.02 \\
\hline Bhtant sterofyping $\rightarrow$ Culture mainterance & -.18 & -0.19 & 0.06 & .003 & -0.32 & -0.05 \\
\hline Undeserved besefits $\rightarrow$ Contact preference & -.16 & -0.18 & 0.06 & .002 & -0.50 & -0.06 \\
\hline Undeserved besefiss $\rightarrow$ Colture maimenance & $-\infty 2$ & -002 & 0.06 & .712 & -0.14 & 0.10 \\
\hline Caltural difference $\rightarrow$ Contact preference & .25 & 029 & 0.05 & $<, 001$ & 0.18 & 0.38 \\
\hline Culoupal difference $\rightarrow$ Cultues maintenance & 14 & 0.15 & 005 & .003 & 0.04 & 0.27 \\
\hline \multicolumn{7}{|l|}{ Slovakia } \\
\hline Blatant stereotyping $\rightarrow$ Contact prefenence & -28 & -0.28 & 006 & $<., 001$ & -0.41 & -0.15 \\
\hline Blatant stecootyping $\rightarrow$ Culture maindenance & -35 & -0.34 & 006 & $<.001$ & -0.47 & -0.22 \\
\hline Undeserved benefits $\rightarrow$ Contast perienese & -.12 & -0.13 & 006 & .031 & -0.26 & -0.01 \\
\hline Undeserved benefits $\rightarrow$ Culture maintenance & -.12 & -0.13 & 006 & .024 & -0.24 & -0.02 \\
\hline Culnural difference $\rightarrow$ Contict preference & .12 & 0.16 & 006 & .004 & 0.05 & 0.28 \\
\hline Cultural difference $\rightarrow$ Culture maintenance & .10 & 0.13 & 005 & .019 & 0,02 & 0.23 \\
\hline \multicolumn{7}{|l|}{ Norway } \\
\hline Btant strrotyping $\rightarrow$ Contact preference & -24 & -0.27 & 000 & .001 & -0.49 & -0.05 \\
\hline Blatant stereotyping $\rightarrow$ Cultuee mainenance & -33 & -0.38 & 008 & $<.001$ & -0.59 & -0.16 \\
\hline Undeserved benefits $\rightarrow$ Contact pecierence & 07 & Q.10 & Q.10 & .289 & -0.12 & 0.31 \\
\hline Undeserved benefits $\rightarrow$ Culture maintenaise & .06 & 0.08 & 0.09 & .408 & -0.13 & 0.25 \\
\hline Culnoral difference $\rightarrow$ Contact preference & 13 & 0.18 & 0.00 & .040 & $<-0.01$ & 0.36 \\
\hline Culnunal difference $\rightarrow$ Cultues mainenance & .18 & 0.27 & 0.00 & .002 & 0.07 & 0.4 \\
\hline \multicolumn{7}{|l|}{ Italy } \\
\hline Bbant secrootyping $\rightarrow$ Contact preference & -39 & -0.43 & 0.07 & $<., 001$ & -0.59 & -0.24 \\
\hline Blasant stetcoryping $\rightarrow$ Culture mainterance & -36 & -0.36 & 006 & $<.001$ & -0.53 & -0.21 \\
\hline Undeserved bresefits $\rightarrow$ Contast perfereace & -01 & -0.01 & 0.07 & 992 & -0.17 & 0.15 \\
\hline Undeserved benefits $\rightarrow$ Culture mainsenance & -03 & -0.03 & 0.07 & .606 & -0.19 & 0.11 \\
\hline Colmeral difference $\rightarrow$ Conbact preference & .18 & 0.27 & 0.07 & $<.001$ & 0.11 & 0.41 \\
\hline Cultoral difference $\rightarrow$ Cultues maintreance & .21 & 0.29 & 0.06 & $<, 001$ & 0.14 & 0.41 \\
\hline \multicolumn{7}{|l|}{ Spoin } \\
\hline Btatant strecotyping $\rightarrow$ Contact preference & -.18 & -0.21 & 0.08 & .013 & -0.37 & -0.03 \\
\hline Blstant stecoofyping $\rightarrow$ Culture maintesance & 30 & -0.30 & 0.07 & $<, 001$ & -0.45 & -0.16 \\
\hline Undeserved benefirs $\rightarrow$ Contset preference & $\omega$ & 0.11 & 0.08 & .211 & -0.06 & 0.28 \\
\hline Undecterved broefits $\rightarrow$ Culture mainhenance & 05 & 0.05 & 0.07 & .487 & -0.09 & 0.19 \\
\hline Coltranal difference $\rightarrow$ Contact prefenence & .04 & 005 & 0.07 & .500 & -0.10 & 0.19 \\
\hline Coltonal difference $\rightarrow$ Cultues maintenance & $\omega$ & 0.10 & 006 & .087 & -0.02 & 0.22 \\
\hline
\end{tabular}

View larger version

The regression paths indicate that across all samples blatant negative stereotyping predicted a lower preference for contact and culture maintenance for the Roma. Regression coefficients were the highest in the Hungarian and the Italian samples, and the weakest in the Romanian sample. Perceived undeserved benefits predicted contact preferences negatively only in Hungary, Romania, and Slovakia, and culture maintenance only among Slovak participants. The Cultural Difference subscale predicted contact intentions and culture maintenance weakly positively in Hungary, Romania, Slovakia, Norway, and Italy, but seemed unrelated to acculturation in Spain. Differences in the strengths of the coefficients were tested with constrained paths (for information on the fit of the constrained models, see Table 5). Only the paths between blatant stereotyping and preference for contact, and between perceived undeserved benefits and preference for contact differed significantly.

Table 5. Model fit information with constrained paths regarding the model in Figure 1. 
Table 5. Model fit information with constrained paths regarding the model in Figure 1.

\begin{tabular}{lcccccccc}
\hline Path & $\chi^{2}$ & $d f$ & CFI & RMSEA & SRMR & $\Delta \chi^{2}$ & $\Delta d f$ & $p$ \\
\hline Blatant stereotyping $\rightarrow$ Contact preference & 20.04 & 5 & .995 & .04 & .01 & 20.04 & 5 & .001 \\
Blatant stereotyping $\rightarrow$ Culture maintenance & 7.38 & 5 & .999 & .02 & .01 & 7.38 & 5 & .194 \\
Undeserved benefits $\rightarrow$ Contact preference & 17.21 & 5 & .996 & .34 & .01 & 17.21 & 5 & .004 \\
Undeserved benefits $\rightarrow$ Culture maintenance & 5.50 & 5 & 1 & .01 & .01 & 5.50 & 5 & .358 \\
Cultural difference $\rightarrow$ Contact preference & 9.05 & 5 & .999 & .02 & .01 & 9.05 & 5 & .107 \\
Cultural difference $\rightarrow$ Culture maintenance & 6.79 & 5 & .999 & .01 & .01 & 6.79 & 5 & .237 \\
\hline
\end{tabular}

View larger version

Explained variance (see Figure 1) also showed variation across samples, more than $28 \%$ of variance of preference for contact was explained by the three dimensions of the ATRS in all samples except for Spain, which showed a mere 5\%. Explained variance in preference for culture maintenance was quite low in Romania $\left(R^{2}=.13\right)$ and Spain $\left(R^{2}=.18\right)$, but above $29 \%$ in all other samples.

\section{Discussion}

This study was a first attempt to investigate the different aspects of anti-Gypsyism crossculturally and identify how they relate to acculturation preferences. The research was conducted with the aim of investigating the potential individual-level psychological obstacles to Roma integration efforts among majority members in different societies. This was necessitated by the lack of previous empirical evidence about acculturation preferences of members of the national majorities of Europe and of information about the predictors of these preferences (for an exception, see Ljujic et al., 2012b). Our data clearly indicated that anti-Gypsyism is an important predictor of acculturation preferences crossculturally, but policy decisions on Roma inclusion should take into account the specific nature of Roma-non-Roma relations in each region of Europe, rather than pursue a "blanket approach" assumed to work across Europe.

Using confirmatory factor analysis, we identified that the three subscales of the ATRS can adequately capture the distinct aspects of anti-Gypsyism within different cultural contexts. This finding supports the idea that attitudes toward the Roma across societies are shaped by traditional negative stereotypes reflecting ideas about violations of moral principles (e.g., beliefs about laziness, criminality). These beliefs resemble old-fashioned prejudice, which research on racism suggested was declining since the 1980s (see McConahay, 1983). The fact that Roma people are still seen through traditionally negative stereotypes may be explained by the specific target perceptions (i.e., prejudice content) that the majority population have about the Roma, which can justify the overt expression of 
prejudice (for a review on target perceptions and prejudice expression, see Kende \& McGarty, 2019). The perceived Undeserved Benefits subscale of the ATRS, which contains items mostly adopted from scales of modern racism, reveals that Roma people are also considered competitors for limited resources, and therefore represent a tangible threat (see Stephan \& Stephan, 2000). This seems particularly relevant in the samples from the three East-Central European countries that are poorer and have a higher Roma population. Therefore, participants from these countries may be more likely to consider any kind of efforts to improve the situation of Roma people as an unfair advantage, and thus a threat to their own well-being. Finally, an independent third factor was identified in all contexts that contains recognition of traditional Roma culture. Although this subscale contains positively worded items, it is only weakly associated with some of the positive attitude measures, and not related to most others. Except for Spain, in all other contexts, the Cultural Difference subscale was (weakly) positively correlated with external motivations to respond without prejudice. This suggests that agreeing with these positively phrased cultural difference items may simply reflect a wish to appear nonprejudiced.

In line with our hypothesis, we found that the inhibition to engage in contact with members of the Roma minority and to accept Roma culture is most strongly and negatively predicted by blatantly negative stereotypes in all six contexts (H1). Stereotypes about Roma people receiving too many and undeserved benefits appeared as a less powerful predictor of acculturation preferences. Specifically, it only appeared as a weak but significant predictor of contact preferences in the three East-Central European countries, in line with our hypothesis (H2). These results suggest that Roma integration strategies may be primarily rejected on the basis of morally framed stereotypes about criminality and laziness, but in the East-Central European context, Roma-non-Roma relations are also interpreted as a realistic conflict. This perception of the intergroup situation is in line with previous research suggesting that economic competition is an important element of acculturation preferences (Zagefka et al., 2007). It is also connected to the political and economic reality of Europe, namely that Roma people constitute a large percentage of the population in those countries where majority members feel relatively deprived themselves compared to countries of Western Europe (a phenomenon often described by the two-speed Europe concept; Yanniris, 2017). The relative importance of perceived undeserved benefits in predicting acculturation preferences in these countries also fits with the assumption that when prejudice is high, people rely on justifying ideologies, such as meritocracy beliefs (i.e., benefits should be earned and not received unconditionally), to reject integration efforts (see Coenders et al., 2001; Kuklinski et al., 1997). 
We measured cultural differences with the expectation that they can either be an expression of positive attitudes (i.e., an appreciation of cultural diversity) or a veiled expression of prejudice (i.e., by suggesting that Roma people are tied to cultural stereotypes from the past; Kligman, 2001; Villano et al., 2017). Insistence on cultural differences has been identified as a veiled form of racism by previous research. That is, when overtly racists stereotypes do not predict attitudinal outcomes, beliefs in cultural difference may continue to do so (Leach et al., 2000). Our results showed that both of these patterns can be found, along with a more ambivalent interpretation of cultural differences in some contexts, but the cultural difference dimension did not, or only very weakly, predicted acculturation outcomes. In sum, the cultural difference dimension may not be a general measure of anti-Gypsyism in the sense that blatant negative stereotyping and perceived undeserved benefits are, but it is a context-dependent measure that can reflect psychological distancing from the group as well as genuine endorsement of cultural diversity. Therefore, we did not receive support for our third hypothesis, as we expected that recognition of cultural differences would be a positive predictor of integration preferences mostly in the contexts of Southern and Northern Europe, but not in EastCentral Europe; however, it seems that cultural difference was a weak positive predictor in all contexts, except for Spain. Indeed, cultural differences did not play a central role in accepting or rejecting Roma integration.

\section{Limitations}

Firstly, we need to acknowledge that our choice of measures has both strengths and limitations. As we have already explained in the introduction section on anti-Gypsyism across Europe, we conceptualized anti-Gypsyism based on the main characteristics of attitudes toward Roma people highlighted by previous research. This approach is reflected in the way the ATRS operationalizes anti-Gypsyism, but it does not include other, possibly similarly relevant attitude dimensions. Furthermore, we relied on a five-item scale of acculturation which measures contact preferences through the limited lens of friendships and interpersonal encounters, and were therefore unable to capture the complexity of intergroup contact with Roma people. It may thus be desirable to use a more complex measure of contact preferences in future research.

We collected data in six European countries and aimed to recruit diverse samples wherever possible. Nonetheless, these samples are not representative of the respective populations, and participants had a higher than average level of education in all six contexts. This 
possibly affected our results, for example, indicated by lower overall levels of prejudice or higher intentions to appear nonprejudiced (see Hello et al., 2002). The sampling method may have affected the data from Spain most strongly, where participants (who were psychology and social work students) showed the lowest level of anti-Gypsyism and lowest frequency of contact. The suboptimal sample size of Norway also necessitates the inclusion of larger and more diverse samples from Northern Europe for more generalizable findings. Specifically, the finding regarding cultural difference as an expression of positive attitudes in Norway as opposed to negative attitudes in Spain should therefore be treated with caution.

Despite the important insights that can be drawn from countries with different normative contexts and different historical presence and demographic patterns of Roma populations, the inclusion of more countries (e.g., Western European countries with a Traveller or Sinti population, and Canada with a recent immigrant minority) could allow for a better identification of context-specific versus transnational trends in Roma inclusion, and increase the validity of the present research.

Finally, despite collecting data in six countries and measuring identical constructs, because of the lack of metric and scalar equivalence, our data were not suitable to offer direct cross-cultural comparisons. Future research may therefore aim to further adjust the ATRS to achieve higher levels of measurement equivalence, for example by generating items that are less sensitive to linguistic differences.

\section{Conclusions}

Our study about attitudes toward Roma people and acculturation preferences in six European countries highlighted that blatant negative stereotyping, that is, hostile and traditional negative stereotypes about the group, is a robust predictor of acculturation preferences among majority members of society. However, in East-Central Europe, where the Roma constitute a large minority group and the countries are relatively poor, Roma people are also rejected on the basis of realistic conflict, associated with the belief that the Roma do not deserve the benefits they receive. It seems that the European values of universalism, humanism, and the consequent norms of egalitarianism and fairness are questioned when it comes to intergroup relations between European national majority groups and Roma people. However, appreciation of traditional Roma culture - that also fits with commonly held stereotypes about the Roma - appears neither as an obstacle to, nor a real driver of integration. We believe that these results point to the importance of 
recognizing anti-Gypsyism - a highly neglected, yet extremely relevant form of ethnic prejudice - as an important element of the resistance to Roma inclusion across Europe. Finally, we conclude that any regional differences in predicting acculturation preferences conditioned by anti-Gypsyism indicate that integration interventions would have to be more context-specific rather than pan-national and general in order to be effective.

\section{Appendix}

Items of the Main Variables of the Study

\section{Attitudes Toward the Roma Scale (Anonymized)}

\section{Blatant Stereotyping subscale}

1. Roma people tend to make more criminal acts than other people.

2. There are very little proper or reasonable Roma people.

3. Roma people do not have a positive relationship to work, they are lazy.

4. The growing Roma population threatens the security of society.

5. Roma people usually have a lot of children, for which they do not give enough care.

6. It is only right that there are still clubs where Roma people are not allowed to enter.

\section{Undeserved Benefits subscale}

1. The real damage is caused by organizations that offer an undeserved advantage to Roma people.

2. Roma people get given more government money than they should be given.

3. I think that Roma people in this country are given preferential treatment in certain aspects.

4. Roma people are very vocal and loud about their rights.

5. The only racial discrimination in [country name] these days is in favor of Roma people.

\section{Cultural Difference subscale}

1. The love of freedom is much stronger among Roma people than among non-Roma [nationality].

2. Music and dancing is something Roma children already learn in the womb.

3. The musical talent of Roma people is superior to that of non-Roma [nationality].

4. We can only envy Roma people's freedom 
5. There is more respect for traditional family values among Roma people than among non-Roma people.

\section{Acculturation Preferences (Zagefka \& Brown, 2002)}

\section{Contact Preference subscale}

1. I think it is important that Roma people have [nationality] friends.

2. I think it is important that [nationality] spend time with Roma people.

\section{Culture Maintenance subscale}

1. I do not mind if Roma people maintain their own culture'

2. I do not mind if Roma people maintain their own religion, language and clothing.

3. I do not mind if Roma people maintain their own way of living.

\section{Authors' Note}

Ana Urbiola is currently affiliated with the University of Almería, Spain.

\section{Funding}

The author(s) disclosed receipt of the following financial support for the research, authorship, and/or publication of this article: This project was funded by the Justice Programme of the European Union (Grant No. 808062) and the National Research and Innovation Fund (Project Nos. 119433 and 119793).

The work of Anna Kende was supported by the New National Excellence Program of the Ministry for Innovation and Technology (Grant No. ÚNKP-19-4) and the János Bolyai Research Scholarship of the Hungarian Academy of Sciences. Barbara Lášticová was supported by the Slovak National Scientific Grant Agency (Grant No. VEGA 2/0127/19).

\section{ORCID iD}

Anna Kende https://orcid.org/0000-0001-5148-0145

\section{Supplemental Material}

Supplemental material for this article is available online.

\section{Notes}

1.The European Commission Against Racism and Intolerance (ECRI, 2011) defines antiGypsyism as a "specific form of racism, an ideology founded on racial superiority, a form 
of dehumanisation and institutional racism nurtured by historical discrimination, which is expressed, among others, by violence, hate speech, exploitation, stigmatisation and the most blatant kind of discrimination."

2.We measured the additional items administered in the original study from Hungary and Slovakia, in case the factors needed to be updated or improved following the new data collection. These items are available in the Open Access database (https://osf.io/789vp/?view_only=2f30870801574e52b4a40ab6f68fed7b), but were eventually not used in the study.

\section{References}

Arbuckle, J. L. (2011). IBM SPSS AMOS 20 user's guide. Chicago, IL: IBM.

Google Scholar

Banaji, M. R., Greenwald, A. G. (1994). Implicit stereotyping and prejudice. In Zanna, M. P., Olson, J. M. (Eds.), The psychology of prejudice: The Ontario Symposium (Vol. 7, pp. 55-76). Hillsdale, NJ: Lawrence Erlbaum Associates.

$\underline{\text { Google Scholar }}$

Barany, Z. (2000). Politics and the Roma in state-socialist Eastern Europe. Communist and PostCommunist Studies, 33, 421-437. http://doi.org/10.1016/S0967-067X(00)00014-3

Google Scholar

Bernát, A., Messing, V. (2016). Methodological and data infrastructure report on Roma population in the EU. Retrieved from https://inclusivegrowth.be/project-output/projectoutput\#Project\%20working\%20papers

Google Scholar

Berry, J. W. (1997). Immigration, acculturation, and adaptation. Applied Psychology: An International Review, 46, 5-68. http://doi.org/10.1111/j.1464-0597.1997.tb01087.x Google Scholar

Bigazzi, S. (2012). Self-image - Gypsy-image. The social representation of Gypsies in the Hungarian and in the Italian context. Magyar Pszichológiai Szemle, 67, 631652. http://doi.org/10.1556/MPSzle.67.2012.4.1 Google Scholar

Bigazzi, S., Csertő, I. (2016). Minority identity strategies bound by prejudice: Restricted perspectives of people categorized as Gypsies. Journal of Community and Applied Social Psychology, 26, 189206. http://doi.org/10.1002/casp.2241

Google Scholar 
Bogardus, E. (1925). Measuring social distance. Journal of Applied Sociology, 9, 299-308. Google Scholar

Bojadjijeva, A. (2015). Roma inclusion index 2015. Retrieved from https://www.rcc.int/romaintegration2020/files/user/docs/Roma\%20Inclusion\%20Index\%202015 .pdf

Google Scholar

Bruneau, E., Szekeres, H., Kteily, N., Tropp, L. R., Kende, A. (2019). Beyond dislike: Blatant dehumanization predicts teacher discrimination. Group Processes \& Intergroup Relations. Advance online publication. http://doi.org/10.1177/1368430219845462

$\underline{\text { Google Scholar }}$

Bye, H. H., Herrebrøden, H., Hjetland, G. J., Røyset, G. Ø., Westby, L. L. (2014). Stereotypes of Norwegian social groups. Scandinavian Journal of Psychology, 55, 469-

476. http://doi.org/10.1111/sjop.12141

Google Scholar

Carrera, S. (2016). Integration of immigrants versus social inclusion: A typology of integration programmes in the EU. In Balzacq, T. (Ed.), Security versus freedom? (pp. 101-126). London, UK: Routledge.

$\underline{\text { Google Scholar } \mid \text { Crossref }}$

Castle, S., Bennhold, K. (2010, September 16). Dispute grows over France's removal of Roma camps. The New York Times. Retrieved

from https://www.nytimes.com/2010/09/17/world/europe/17union.html?_r=1\&scp=1\&sq=Roma\%20

France\&st=cse

Google Scholar

Clark, C. (1998). Counting backwards: The Roma "numbers game" in Central and Eastern Europe. Radical Statistics, 69, 35-46.

$\underline{\text { Google Scholar }}$

Coenders, M., Scheepers, P., Sniderman, P. M., Verberk, G. (2001). Blatant and subtle prejudice:

Dimensions, determinants, and consequences; some comments on Pettigrew and Meertens. European Journal of Social Psychology, 31, 281-297. http://doi.org/10.1002/ejsp.44

$\underline{\text { Google Scholar }}$

Cook, B., Wayne, G. F., Valentine, A., Lessios, A., Yeh, E. (2013). Revisiting the evidence on health and health care disparities among the Roma: A systematic review 2003-2012. International Journal of Public Health, 58, 885-911. http://doi.org/10.1007/s00038-013-0518-6

Google Scholar 
Cooper, B. (2001). "We have no Martin Luther King": Eastern Europe's Roma minority. World Policy Journal, 18, 69-78. http://doi.org/10.1215/07402775-2002-1001

Google Scholar

Csepeli, G. (2010). Gypsies and gadje: The perception of Roma in Hungarian society. Central European Political Science Review, 11, 62-78.

Google Scholar

Csepeli, G., Simon, D. (2004). Construction of Roma identity in Eastern and Central Europe:

Perception and self-identification. Journal of Ethnic and Migration Studies, 30, 129

150. http://doi.org/10.1080/1369183032000170204

Google Scholar

Dahlgreen, W. (2015). Roma people and Muslims are the least tolerated minorities in Europe.

Retrieved from https://yougov.co.uk/topics/politics/articles-reports/2015/06/05/european-attitudes$\underline{\text { minorities }}$

Google Scholar

Dalsklev, M., Kunst, J. R. (2015). The effect of disgust-eliciting media portrayals on outgroup dehumanization and support of deportation in a Norwegian sample. International Journal of Intercultural Relations, 47, 28-40. http://doi.org/10.1016/j.ijintrel.2015.03.028

Google Scholar

Dovidio, J. F., Gaertner, S. L. (1986). Prejudice, discrimination, and racism: Historical trends and contemporary approaches. San Diego, CA: Academic Press.

$\underline{\text { Google Scholar }}$

Dovidio, J. F., Gaertner, S. L. (2000). Aversive racism and selection decisions: 1989 and 1999.

Psychological Science, 11, 315-319. http://doi.org/10.1111/1467-9280.00262

Google Scholar

Duckitt, J. (2001). A dual-process cognitive-motivational theory of ideology and prejudice. Advances in Experimental Social Psychology, 33, 41-113. http://doi.org/10.1016/S0065-2601(01)80004-6 Google Scholar

Dunbar, E., Simonova, L. (2003). Individual difference and social status predictors of anti-Semitism and racism US and Czech findings with the prejudice/tolerance and right wing authoritarianism scales. International Journal of Intercultural Relations, 27, 507-523. http://doi.org/10.1016/S0147$\underline{1767(03) 00051-8}$

Google Scholar

Enyedi, Z., Fábián, Z., Sik, E. (2004). Is prejudice growing in Hungary? Changes in anti-Semitism, anti-Roma feeling and xenophobia over the last decade. In Kolosi, T., Tóth, I. G., Vukovich, G. 
(Eds.), Social report 2004 (Vol. 21, pp. 363-385). Budapest, Hungary: Tárki.

Google Scholar

European Commission . (2004). The situation of Roma in an enlarged European Union. Retrieved from http://www.errc.org/uploads/upload_en/file/00/E0/m000000E0.pdf

Google Scholar

European Commission . (2015). Discrimination in the EU in 2015. Retrieved

from http://dx.doi.org/10.2838/325154

Google Scholar

European Commission . (2018). Civil society monitoring report on implementation of the national Roma integration strategies in Italy. Retrieved

from https://cps.ceu.edu/sites/cps.ceu.edu/files/attachment/basicpage/3034/rcm-civil-society-

monitoring-report-1-italy-2017-eprint-fin.pdf

Google Scholar

European Commission Against Racism and Intolerance (ECRI) . (2011). ECRI General Policy

Recommendation No. 13 on combating anti-Gypsyism and discrimination against Roma. Retrieved

from https://www.coe.int/en/web/european-commission-against-racism-and-

intolerance/recommendation-no.13

Google Scholar

European Roma Rights Centre (ERRC) . (2000). Campland: Racial segregation of Roma in Italy.

Retrieved from http://www.errc.org/reports-and-submissions/campland-racial-segregation-of-roma-initaly

Google Scholar

European Union . (2019). Eurostat regional yearbook. 2019 edition. Retrieved

from https://ec.europa.eu/eurostat/documents/3217494/10095393/KS-HA-19\%E2\%80\%91001-EN-

N.pdf/d434affa-99cd-4ebf-a3e3-6d4a5f10bb07

Google Scholar

European Union Agency for Fundamental Rights (FRA) . (2016). Second European Union minorities and discrimination survey: Roma - Selected findings. Retrieved

from https://fra.europa.eu/en/publication/2016/eumidis-ii-roma-selected-findings

Google Scholar

European Union Agency for Fundamental Rights (FRA) . (2018). FRA opinions anti-Gypsyism:

Discrimination, harassment and hate crime. Retrieved

from https://fra.europa.eu/en/publication/2018/roma-inclusion/fra-opinions

Google Scholar 
Fontanella, L., Villano, P., Di Donato, M. (2016). Attitudes towards Roma people and migrants: A comparison through a Bayesian multidimensional IRT model. Quality \& Quantity, 50, 471490. http://doi.org/10.1007/s11135-014-0158-9

Google Scholar

González, R., Sirlopú, D., Kessler, T. (2010). Prejudice among Peruvians and Chileans as a function of identity, intergroup contact, acculturation preferences, and intergroup emotions. Journal of Social Issues, 66, 803-824. http://doi.org/10.1111/j.1540-4560.2010.01676.x

Google Scholar

Hello, E., Scheepers, P., Gijsberts, M. (2002). Education and ethnic prejudice in Europe: Explanations for cross-national variances in the educational effect on ethnic prejudice. Scandinavian Journal of Educational Research, 46, 5-24. http://doi.org/10.1080/00313830120115589

Google Scholar

Kende, A., Hadarics, M., Lášticová, B. (2017). Anti-Roma attitudes as expressions of dominant social norms in Eastern Europe. International Journal of Intercultural Relations, 60, 12

27. http://doi.org/10.1016/j.ijintrel.2017.06.002

Google Scholar

Kende, A., McGarty, C. (2019). A model for predicting prejudice and stigma expression by understanding target perceptions: The effects of visibility, politicization, responsibility, and entitativity. European Journal of Social Psychology, 49, 839-856. http://doi.org/10.1002/ejsp.2550 $\underline{\text { Google Scholar }}$

Kligman, G. (2001). On the social construction of "otherness": Identifying "the Roma" in postsocialist communities. Review of Sociology, 7, 61-78. http://doi.org/10.1556/RevSoc.7.2001.2.4 $\underline{\text { Google Scholar }}$

Kteily, N., Bruneau, E., Waytz, A., Cotterill, S. (2015). The ascent of man: Theoretical and empirical evidence for blatant dehumanization. Journal of Personality and Social Psychology, 109, 901931. http://doi.org/10.1037/pspp0000048

Google Scholar

Kuklinski, J. H., Sniderman, P. M., Knight, K., Piazza, T., Tetlock, P. E., Lawrence, G. R., Mellers, B. (1997). Racial prejudice and attitudes toward affirmative action. American Journal of Political Science, 41, 402-419. http://doi.org/10.2307/2111770

Google Scholar

Kunst, J. R., Sadeghi, T., Tahir, H., Sam, D., Thomsen, L. (2016). The vicious circle of religious prejudice: Islamophobia makes the acculturation attitudes of majority and minority members clash. European Journal of Social Psychology, 46, 249-259. http://doi.org/10.1002/ejsp.2174 Google Scholar 
Largent, E. A., Grady, C., Miller, F. G., Wertheimer, A. (2012). Money, coercion, and undue inducement: A survey of attitudes about payments to research participants. IRB Ethics and Human Research, 34, 1-8.

Google Scholar $\mid \underline{\text { Medline }}$

Lášticová, B., Findor, A. (2016). Developing explicit measures of stereotypes and anti-Roma prejudice in Slovakia: Conceptual and methodological challenges. Human Affairs, 26, 233252. http://doi.org/10.1515/humaff-2016-0022

Google Scholar

Leach, C. W., Peng, T. R., Volckens, J. (2000). Is racism dead? Comparing (expressive) means and (structural equation) models. British Journal of Social Psychology, 39, 449-

465. http://doi.org/10.1348/014466600164507

Google Scholar

Ljujic, V., Vedder, P., Dekker, H., van Geel, M. (2012a). Romaphobia: A unique phenomenon? Romani Studies, 22, 141-152. http://doi.org/10.3828/rs.2012.8

$\underline{\text { Google Scholar }}$

Ljujic, V., Vedder, P., Dekker, H., van Geel, M. (2012b). Serbian adolescents' Romaphobia and their acculturation orientations towards the Roma minority. International Journal of Intercultural Relations, 36, 53-61. http://doi.org/10.1016/j.ijintrel.2010.11.015

Google Scholar

Ljujic, V., Vedder, P., Dekker, H., van Geel, M. (2013). Romaphobia among Serbian and Dutch adolescents: The role of perceived threat, nationalistic feelings, and integrative orientations. International Journal of Psychology, 48, 352-362. http://doi.org/10.1080/00207594.2012.661060 $\underline{\text { Google Scholar }}$

López Catalán, Ó. (2012). The genesis of a "Romanian Roma issue" in the metropolitan area of Barcelona: Urban public spaces, neighbourhood conflicts and local politics. Revista de Estudios Urbanos y Ciencias Sociales, 2, 95-117.

Google Scholar

Loveland, M. T., Popescu, D. (2016). The Gypsy threat narrative explaining anti-Roma attitudes in the European Union. Humanity \& Society, 40, 329-352. http://doi.org/10.1177/0160597615601715 $\underline{\text { Google Scholar }}$

MacCallum, R. C., Widaman, K. F., Zhang, S., Hong, S. (1999). Sample size in factor analysis. Psychological Methods, 4, 84-99. http://doi.org/10.1037/1082-989X.4.1.84

Google Scholar 
Magazzini, T., Piemontese, S. (2016). Roma migration in the EU: The case of Spain between "new" and "old" minorities. Migration Letters, 13, 228-241. http://doi.org/10.33182/ml.v13i2.304 Google Scholar

Marushiakova-Popova, E., Popov, V. (2015). European policies for social inclusion of Roma: Catch 22? Social Inclusion, 3, 19-31. http://doi.org/10.17645/si.v3i5.241

Google Scholar

McConahay, J. B. (1983). Modern racism and modern discrimination: The effects of race, racial attitudes, and context on simulated hiring decisions. Personality and Social Psychology Bulletin, 9, 551-558. http://doi.org/10.1177/0146167283094004

Google Scholar

Mušinka, A., Škobla, D., Hurrle, J., Matlovičová, K., Kling, J. (2014). ATLAS rómskych komunít na Slovensku 2013 [Atlas of Roma communities in Slovakia 2013]. Bratislava, Slovakia: UNDP. Google Scholar

Nariman, H. S., Hadarics, M., Soufizadeh, A. M., Kende, A. (2020). The mediating role of moral exclusion between authoritarianism and outgroup discrimination. International Journal of Intercultural Relations, 74, 1-6. http://doi.org/10.1016/j.ijintrel.2019.10.001

$\underline{\text { Google Scholar }}$

$\mathrm{Ng}, \mathrm{R}$. V. (2017). Evaluating the treatment of the Roma population within the EU. In Claremont-UC Undergraduate Research Conference on the European Union. http://doi.org/10.5642/urceu.201701.11 Google Scholar

Orosz, G., Bruneau, E., Tropp, L. R., Sebestyén, N., Tóth-Király, I., Bőthe, B. (2018). What predicts anti-Roma prejudice? Qualitative and quantitative analysis of everyday sentiments about the Roma. Journal of Applied Social Psychology, 48, 317-328. http://doi.org/10.1111/jasp.12513 Google Scholar

Pásztor, I. Z., Pénzes, J. (2013). Studying the number of the Gypsy minority in Hungary and their involvement in local governments on the example of the North Great Plain region. Revista Română de Geografie Politică, 15, 17-26.

Google Scholar

Pedersen, A., Beven, J., Walker, I., Griffiths, B. (2004). Attitudes toward indigenous Australians: The role of empathy and guilt. Journal of Community \& Applied Social Psychology, 14, 233 249. http://doi.org/10.1002/casp.771

Google Scholar

Pérez, J. A., Moscovici, S., Chulvi, B. (2007). The taboo against group contact: Hypothesis of Gypsy ontologization. British Journal of Social Psychology, 46, 249- 
Pettigrew, T. F., Meertens, R. W. (1995). Subtle and blatant prejudice in Western Europe. European Journal of Social Psychology, 25, 57-75. http://doi.org/10.1002/ejsp.2420250106

Google Scholar

Phinney, J. S., Horenczyk, G., Liebkind, K., Vedder, P. (2001). Ethnic identity, immigration, and well-being: An interactional perspective. Journal of Social Issues, 57, 493-

510. http://doi.org/10.1111/0022-4537.00225

Google Scholar

Piontkowski, U., Florack, A., Hoelker, P., Obdrzálek, P. (2000). Predicting acculturation attitudes of dominant and non-dominant groups. International Journal of Intercultural Relations, 24, $1-$

26. http://doi.org/10.1016/s0147-1767(99)00020-6

Google Scholar

Plant, E. A., Devine, P. G. (1998). Internal and external motivation to respond without prejudice. Journal of Personality and Social Psychology, 75, 811-832. https://doi.org/10.1037/0022-

$\underline{3514.75 .3 .811}$

Google Scholar

Popoviciu, S., Tileagă, C. (2019). Subtle forms of racism in strategy documents concerning Roma inclusion. Journal of Community \& Applied Social Psychology. Advance online

publication. http://doi.org/10.1002/casp.2430

Google Scholar

Roma Education Fund . (2012). Country assessment: Romania. Retrieved from https://www.romaeducationfund.org/wpcontent/uploads/2019/05/ref_ca_2011_ro_english_screen_singlepages.pdf Google Scholar

Rosvoll, M., Bielenberg, N. (2012). Antisiganisme, stereotípier og diskriminering av rom [AntiGypsyism, stereotyping and discrimination against Roma people]. Retrieved from https://www.hlsenteret.no/aktuelt/publikasjoner/digitale-hefter/pdf/hl_temahefte_14_digital.pdf Google Scholar

Rudmin, F. W., Ahmadzadeh, V. (2001). Psychometric critique of acculturation psychology: The case of Iranian migrants in Norway. Scandinavian Journal of Psychology, 42, 41-

56. http://doi.org/10.1111/1467-9450.00213

Google Scholar

Sándor, J., Kósa, Z., Boruzs, K., Boros, J., Tokaji, I., McKee, M., Ádány, R. (2017). The decade of Roma inclusion: Did it make a difference to health and use of health care services? International 
Journal of Public Health, 62, 803-815. http://doi.org/10.1007/s00038-017-0954-9

Google Scholar

Schwartz, S. H., Bardi, A. (2001). Value hierarchies across cultures: Taking a similarities perspective. Journal of Cross-Cultural Psychology, 32, 268-290. http://doi.org/10.1177/0022022101032003002 Google Scholar

Sears, D. O. (1986). College sophomores in the laboratory: Influences of a narrow data base on social psychology's view of human nature. Journal of Personality and Social Psychology, 51, 515-

530. http://doi.org/10.1037/0022-3514.51.3.515

Google Scholar

Sherif, M. (1966). Group conflict and co-operation: Their social psychology. London, UK: Routledge \& Kegan Paul.

Google Scholar

Sidanius, J., Pratto, F. (1999). Social dominance: An intergroup theory of social hierarchy and oppression. Cambridge, UK: Cambridge University Press.

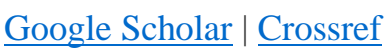

Sigona, N. (2005). Locating "the Gypsy problem.” The Roma in Italy: Stereotyping, labelling and "nomad camps." Journal of Ethnic and Migration Studies, 31, 741-

756. http://doi.org/10.1080/13691830500109969

Google Scholar

Stephan, W. G., Stephan, C. W. (2000). An integrated threat theory of prejudice. In Oskamp, S. (Ed.), Reducing prejudice and discrimination (pp. 23-45). Mahwah, NJ: Lawrence Erlbaum Associates. Google Scholar

Stewart, M. S. (2012). The Gypsy menace: Populism and the new anti-Gypsy politics. London, UK: Hurst \& Company.

Google Scholar

Stokes, B. (2015). Chapter 3. Anti-minority sentiment not rising. Retrieved from Pew Research Center website: http://www.pewglobal.org/2015/06/02/chapter-3-anti-minority-sentiment-not-rising/ Google Scholar

Todosijevic, B., Enyedi, Z. (2002). Authoritarianism vs. cultural pressure: Anti-Gypsy prejudice in Hungary. Journal of Russian \& East European Psychology, 31, 31-

54. http://doi.org/10.2753/RPO1061-0405400531

Google Scholar

Tremlett, A. C., Messing, V. (2015). Hungary's future: Anti-immigration, anti-multiculturalism and anti-Roma? Retrieved from https://www.opendemocracy.net/en/can-europe-make-it/hungarys-future- 
antiimmigration-antimulticulturalism-and-antiro/

Google Scholar

Urbiola, A., Willis, G. B., Ruiz-Romero, J., Moya, M. (2018). Does a multicultural perspective shape unbiased minds? The moderating role of outgroup threat. Journal of Applied Social Psychology, 48, 608-617. http://doi.org/10.1111/jasp.12551

Google Scholar

Vandenberg, R. J., Lance, C. E. (2000). A review and synthesis of the measurement invariance literature: Suggestions, practices, and recommendations for organizational research. Organizational Research Methods, 3, 4-70. http://doi.org/10.1177/109442810031002

$\underline{\text { Google Scholar }}$

Váradi, L. (2014). Youths trapped in prejudice: Hungarian adolescents' attitudes towards the Roma. New York, NY: Springer Science \& Business.

$\underline{\text { Google Scholar | Crossref }}$

Villano, P., Fontanella, L., Fontanella, S., Di Donato, M. (2017). Stereotyping Roma people in Italy: IRT models for ambivalent prejudice measurement. International Journal of Intercultural Relations, 57, 30-41. http://doi.org/10.1016/j.ijintrel.2017.01.003

Google Scholar

Weinerová, R. (2014). Anti-Gypsyism in the Czech Republic: Czechs' perception of Roma in cultural stereotypes. Acta Ethnographica Hungarica, 59, 211-221. http://doi.org/10.1556/AEthn.59.2014.1.10 Google Scholar

Yanniris, C. (2017). Diversified economic governance in a multi-speed Europe: A buffer against political fragmentation? Journal of Contemporary European Research, 13, 1412-1421. Google Scholar

Zagefka, H., Binder, J., Brown, R., Kessler, T., Mummendey, A., Funke, F., . . Maquil, A. (2014). The relationship between acculturation preferences and prejudice: Longitudinal evidence from majority and minority groups in three European countries. European Journal of Social Psychology, 44, 578-589. http://doi.org/10.1002/ejsp.2044

Google Scholar

Zagefka, H., Brown, R. (2002). The relationship between acculturation strategies, relative fit and intergroup relations: Immigrant-majority relations in Germany. European Journal of Social Psychology, 32, 171-188. http://doi.org/10.1002/ejsp.73

Google Scholar

Zagefka, H., Brown, R., Broquard, M., Martin, S. L. (2007). Predictors and consequences of negative attitudes toward immigrants in Belgium and Turkey: The role of acculturation preferences and economic competition. British Journal of Social Psychology, 46, 153- 
169. http://doi.org/10.1348/014466606X111185

Google Scholar

Zagefka, H., Brown, R., González, R. (2009). Antecedents and consequences of acculturation preferences of non-indigenous Chileans in relation to an indigenous minority: Longitudinal survey evidence. European Journal of Social Psychology, 39, 558-575. http://doi.org/10.1002/ejsp.550 Google Scholar

Zick, A., Küpper, B., Hövermann, A. (2011). Intolerance, prejudice and discrimination: A European report. Retrieved from http://library.fes.de/pdf-files/do/07908-20110311.pdf

Google Scholar

Zick, A., Wagner, U., van Dick, R., Petzel, T. (2001). Acculturation and prejudice in Germany: Majority and minority perspectives. Journal of Social Issues, 57, 541-

557. http://doi.org/10.1111/0022-4537.00228

Google Scholar 